\title{
WOMAN AS ACTRESS OF TRADITIONAL PERFORMING ARTS AND GENDER JUSTICE IN EAST JAVA
}

\author{
Arif Budi Wurianto
}

The University of Muhammadiyah Malang

\begin{abstract}
Main problem is whether gender justice and equality in art performance, mainly in traditional art performance, have become central issues in efforts to socialize and as a gender mainstream in Education, Law, Economy, Politic, and Social. In general and traditional art performance, woman always involved, especially the main actresses in various art performances, they are adored both as 'diva or idol' who are able to attract people and also are humiliated because, in some occasions, she shows her over-sensuality so that it humiliates her dignity as a woman. The both positions generate a number of questions about position of gender mainstream and its advocating.
\end{abstract}

\section{INTRODUCTION}

There is statement that in art woman is also marginalized. The meaning of the above statement is very deep, because in the world of art, such as art of literature, performance art, sculpture art, recording art, skill art, and so on, woman, beside as an object of art work, in the process of art action, she also has never got responsive justice and equality gender. Art constitutes a human cultural product that neutral in gender, both man and woman have equality in creation and utilize it for social and cultural life. In the life of traditional performance art, woman is much involved, both as an actress of active art and as performance organizer. Woman often identified as a powerless art object. Even, in traditional performance art that should be neutral in gender, woman is involved in stressing a brand suffering gender inequality and injustice. This is a gender injustice and a gender inequality for woman in getting the same rights both as actress and art performance organizer.

Results of some researches inform that there are still unbalancing in the society about certain values that cornering woman as an actress in art performance in expressing their art acting. Nevertheless, income received by actress is not balance with her professionalism only because she is a woman. Woman as an organizer often finds difficulties to get access of credit for art performance and lobby of cultural communication only because she is a woman. Beside that, there is still negative perspective to woman as an actress because of its performance schedule and their involvement with many people. Based on the reality of woman as an actress in traditional art performance, it needs other perspective in viewing woman as she conducting their traditional art performance activities. This new perspective could be started from redefinition based on the cultural 
studies as basis for providing new paradigms that refer to conceptual in nature. The redefinition is done as a starting point of efforts to advocate woman, find concept and steps of participatory strategy in helping woman who active in public sector in traditional art performance to get her gender justice.

Yet, gender injustice is caused by the existing social construct. Patriarchy tradition makes woman is marginalized and get gender injustice and always been as an art object that lead to show her sexual exotics in art, this ultimately lead to sexual flatter that offend woman self-dignity and self-esteem. Moreover, beside as a sexual object in art exotics, there are many cases indicating that woman as a subject to sell their sensuality in art activities, especially in modern popular art and recording.

Main problem is whether gender justice and equality in art performance, mainly in traditional art performance, have become central issues in efforts to socialize and as a gender mainstream in Education, Law, Economy, Politic, and Social. Gender issue is, of course, a cultural issue, but cultural aspects inside seldom discussed whereas it is the social issue that needs aids and advocating. Some issues have happened related with this problem. One research showed that, for example, woman in art of 'Reog Ponorogo' in East Java, it revealed that 'Reog Ponorogo' performance with its 'jathil' woman dancer, beside she brings the art of 'Reog Ponorogo' as increasingly appreciated by wider societies, it also generate injustice treatment to 'jathil' dancer that lead to discriminative and exploitative treatment. This injustice treatment happened, mainly in performance of 'reog obyok', where its dancer performance seems free and unrestricted. The injustice treatment includes; sexual flatter, through momentum of 'saweran' (chances for audience, mainly men, to dance together with her while giving tip by touching body of the 'jathil' dancer; woman is forced to obey to man through 'edreg' dance ('jathil' dancer gives respond in the form of captive attitude to 'barongan' and 'ganongan' dancers every after performing her dance); the attribute of easy-woman to 'jathil' dancer is caused by costume models (gaudy in dress and makeup or more stressed in beautiful makeup so it looks as a seducer woman); and even there is brand as prostitute woman is caused by pattern of taking and dropping woman that are not appropriate with time schedule agreed by society where the dancer lives, both when exercising and performing in a stage (Ekapti Wahyuni, 2008). These examples constitute some cases from many art performances in East Java or Indonesia that are various.

$$
\text { Related with world }
$$

conference about Woman IV in Beijing 1995 that resulted in Beijing Platform for Action with basis of action focusing on 12 critical points, there are some points referred dealing with woman rights and woman dignity in traditional art performance. These points are: Woman and Poverty, Violence to Woman, Woman and Economy, woman in authority and decision taking, and rights for woman. These 
points have close relation to the woman role in traditional art performance because, beside as a form of intellectual and talent capacity in art action, traditional art performance is also as a part of economy expression activities that susceptible to woman flatter and injustice.

\section{Woman in Traditional Art Performance '}

In general and traditional art performance, woman always involved, especially the main actresses in various art performances, they are adored both as 'diva or idol' who are able to attract people and also are humiliated because, in some occasions, she shows her oversensuality so that it humiliates her dignity as a woman. The both positions generate a number of questions about position of gender mainstream and its advocating.

Special case could be given, for example, position of Tayub dance in Ngadisari, Tengger Highland when there is ritual in ceremony sequence of 'Kasada', position of dancer is respected as theme of ritual central symbolism. Likewise, when 'tayuban' is playing, there is no practice of sexual flatter like 'saweran' or giving money by inserting in part of the woman body as many tayuban do in some places. Some cases of dignity humiliating of woman actress, for example, in one of 'puppet show' play, when comedian 'limbukan or gara-gara' which is now often filled with song request from 'dalang' to 'pesinden', or material of comedian that often conducting sexual flatter through words and nonverbal language to woman. Woman often been treated as an object of masculine authority. Masculine authority indicates man views to woman and social perception about relationship between man and woman based on the existing values and norms.

Woman used as agent of change in tradition of Reog Ponorogo. When government transfers 'jadhil' dancer position from man to woman in various festivals and performance, it gives positive assessment about acceptability of people appreciation to this reog art. Yet, in the further development, this art changes that they are defeated by masculinity in art performance.

Nevertheless, in case of Gandrung art in Banyuwangi, popularity of Gandrung makes this performance becomes 'cultural icon' in the city. Meanwhile, Gandrung is identical with woman dancer. Two sides accompanying the art of Gandrung are (1) gandrung actresses feel that they get cultural acknowledgement, so that their talent and capacity constitute her dignity as subject, (2) in the other side, during gandrung playing, there is always violation to morality norms, for example, drug or giving money (tip) to dancer, these generate people's negative assessment, so that gandrung woman dignity is cornered, (3) this second side triggers assumption from the religious group to give distinction assessment, (4) issue of performance management that susceptible to injustice gender.

Madura seems identical to religious society and seldom related to traditional art performance, based 
on Elanie Bouvier research (2004), in fact, in part of Northern Madura also preserves traditional art performance where woman also involved. One of Madura traditional art that involves woman is 'Tandha'. Behind this people's art, there is man's authority that triggers gender injustice. Actually it is not only happened in Madura, almost all pair dances, certainly, inserted man's authority to woman in the form of sexual subject and object. Yet, based on research by Riansyah and Ahmad Zainul Hamdi (2007) reported that woman role in traditional art is vary, such as phenomenon of woman as pengrawit and sinden di Northern Madura island that utilize traditional art performance as a place to seek a living for their family. There are roles of financial manager in art group management and, of course, there is always efforts to look for new young and beautiful actress, beside they must face their husband and society with their different opinion and views.

Woman as Actress of Traditional Art Performance in the Social Space and Patriarch Authority

Traditional art performance that is still supported by people with their local traditional culture provides phenomenon of social space for woman actress and their powerless on the patriarch authority. Woman position in the traditional art performance is not far from their function and role in the traditional art performance in the sequence of history. In the past, traditional art performance always played by man. Some example can be mentioned on art performance of Ludruk in East
Java where all players are man. Player of woman is played by transvestite man. Presently, although there is still transvestite man, yet woman has taken over this role. There are two reasons for this, i.e.:

(1) As a job chance for woman;

(2) As an art innovation and opportunity for woman to express.

Wayang orang shows in the royal palace, in the past, also played by man, including player of woman character. This continued until 1930. Afterward, there is a change where woman character is played by woman. In some chances, there is cross gender actor where man character is played by woman. Other example, there is waranggana puppet show that usually played by woman, now it is played by man because their voice like a woman, such as, man from Wonogiri, Central Java, who becomes part of puppet show of Ki Anom Suroto. What the problem now is among ability, economy, and emotional comfort. Of course, it is not easy to do this job, although according to the art history, in the past, there was also story/legend/myth revealing that singer is originally from man who has voice like woman both in around of Gods and human being. Based on the above example, it can be categorized that position of traditional art actors is in position as transvestite, (2) relationship between woman and man in traditional art performance is in the position of cross gender, (3) relationship between woman and man in traditional art performance is in the position of substitution in the meaning of woman position can be 
substituted by man and conversely. Moreover in this relationship, their role in traditional art performance is done because of their ability in art, beside also as a means to get economic income, how is the justice position and gender equality in the social relations?

Woman as actress of traditional art performance in social space and patriarch authority constitute a paradox. There is no gender difference between man and woman in terms of expression. What the problem is the meaning of their role and public space. Clifford Geertz (1973) mentioned it as human who deceived in the net that they spin by themselves. Mary Douglas (in Simatupang, 2005: viii) categorized human body into physical and social body, economy body, and symbolic body. Various statements confirm the important meaning of a body in human life. Meanwhile, Alma Gottlieb (in Simatupang, 2005: viii) stated that inherent in physical body there are social body and natural body that are intervened and arranged and also make it as human body (cultural body) from woman (female) and man (male) that ultimately create woman and man. In traditional art performance, often happened cross gender playing where woman character is played by man or man character is played by woman.

Woman as actress in traditional art performance, in some cases, still occurred 'body borrowing'. There are many realities in the traditional art performance in Indonesia where ones borrow body for a character or woman as the role subject. In gender relation, it needs explanation about the meaning of (1) man plays as woman character (female impersonator), (2) woman character played by man transvestite as the spiritual meaning for getting purity, (3) social and cultural engineering from cross gender phenomenon in art performance, and (4) role of limens position of man in woman character as phenomenon of man sinden in puppet show, and (5) in each body of both man and woman as subject.

Female impersonator or man player who plays as woman character constitutes an illustration of character in art performance that utilizes man to play woman character. It can happen, for example, in wayang topeng, Malang, Wayang Gong in Bali, Arja in Bali, or wayang topeng in the Royal Palace in Java. It is based on various factor, for example, spiritual reason and belief or skill factor of traditional art performance by man. Actually, if it is played by woman herself is no problem, yet, cultural reason will become a problem. In turn, man character that is played by woman is an innovation of gender relationship. It can be seen from Dolalak art in Purworejo Regency, Central Java. In this art, there are religious, magic, and social elements that are played by woman as representation of symbol system in the history of Dolalak art. There is balancing among social, politic, economy and cultural access from this art performance (Prihartini, 2003).

Woman character is played by transvestite man as a spiritual body meaning for getting 'purity'. This is based on the developed myths 
in the society. An actor, Ki Soleh Adipramono from Tumpang, Malang, states that if we review from art history in Nusantara, why are there man and woman? And also why is there not man and not woman? In popular we call them banci, wadam, waria, and technically we call them as transsexual or transvestite. This is caused by their role as purifier from the world that has been polluted by man and woman, they function as mediator. Although it is not in the field of art performance, bassu (The Royal Buton Monks) in South Sulawesi also function as mediator and guard of the world purity. Apart from this reason, role of transvestite like Ludruk in East Java, in soma cases, also help them in working and looking for income because in outside of the art performance they are find difficult to get job as their nature. In some cases, surely, they try to play a role of woman as originally. Now, in Jombang and Mojokerto, and Surabaya, it is starting to develop woman character that is played by real woman in Ludruk, with various reasons, for example, as her seeking for living, as her additional seeking for living, as hobby, or as conservation program of Province Cultural Agency for cultural mission. Woman in social and cultural engineering derives from phenomenon of cross gender in art performance. This is new thing in art performance. Art innovation developed by Mr. Didik Hadiprayitno (Didik Nini Thowok) from Yogyakarta, who, in some occasions, often plays dancing in woman character. He acts, dresses, makeup, all in woman. Certainly, not only in Indonesia, In Japan, Kabuki and Takarazuka art are also utilize cross gender as a tradition. Social and cultural engineering are more viewed as an art creation with domination of man entering to woman world. But in a case of Arja art performance in Bali, there are many names and characters of woman are played by actors.

Limens position role of man in the woman character is man (pure) who has ability and also has voice like woman. This is happened in some cases and the relationship of gender is not a problem except there are some social views. For example, in case of Wiyarto, a man who has ability to be a sinden because he has voice like woman and he sit in balance with woman sinden in accompanying puppet show of $\mathrm{Ki}$ Anom Suroto. Similar case also happened in Sunda.

Role as a subject in each man and woman body, called 'self'. With all nature and ability they have, both man and woman act as characters and functions in traditional art performance. In this 'self', gender unbalance is easy to intervene, started from violence in language, sexual, emotional, and psychology and in some cases related with social and art performance in stage.

Cross gender in art performance of one self is licentia poetika or rights in expressing and contemplating, yet, in some terms in traditional art environment and in traditional conservative people often there are many ethic norms and tight esthetic, such as woman limitation in art action like how to look with eyes, how to lift one foot, how to put leg, how to step (leap), mainly in dances, 
they should be adapted with character of woman. In nature and in the construct of society culture state that woman should be delicate, polite, ethic, with little movement and speak. Meanwhile, handsome man player is also susceptible to social like the easiness to attract woman both young girl and young mother, and so on. Moreover, transvestite man and woman have susceptible in norm and ethic issues about the same-gender relationship, and so on. Woman, in traditionally, is not polite to be object of shows. Limitation of woman ethic to act in art performance and domination of man in the roles of art performance, certainly, become issue of gender reaction in social, economy and culture.

Position and condition of man and woman in traditional art performance including social, economy and cultural acceptance can be seen in table below:
Table. 1

Position and Condition of Man and Woman in Traditional Art Performance

\begin{tabular}{|c|c|c|c|c|}
\hline \multirow[b]{2}{*}{ No } & \multirow[b]{2}{*}{ Position } & \multicolumn{3}{|c|}{ Acceptance } \\
\hline & & Social & $\begin{array}{c}\text { Econo } \\
\text { my }\end{array}$ & $\begin{array}{c}\text { Cultu } \\
\text { re }\end{array}$ \\
\hline 1 & $\begin{array}{l}\text { Female } \\
\text { imperso } \\
\text { nator }\end{array}$ & $\begin{array}{l}\text { accept } \\
\text { ed }\end{array}$ & $\begin{array}{l}\text { accepte } \\
\text { d }\end{array}$ & $\begin{array}{l}\text { Acce } \\
\text { pted }\end{array}$ \\
\hline 2 & $\begin{array}{l}\text { Woman } \\
\text { character } \\
\text { played } \\
\text { by } \\
\text { transvest } \\
\text { ite man } \\
\text { as } \\
\text { spiritual } \\
\text { body } \\
\text { meaning } \\
\text { for } \\
\text { getting } \\
\text { purity }\end{array}$ & $\begin{array}{l}\text { accept } \\
\text { ed }\end{array}$ & $\begin{array}{l}\text { accepte } \\
\text { d }\end{array}$ & $\begin{array}{l}\text { Acce } \\
\text { pted }\end{array}$ \\
\hline 3 & $\begin{array}{l}\text { Engineer } \\
\text { ing of } \\
\text { social } \\
\text { and } \\
\text { culture } \\
\text { from } \\
\text { cross } \\
\text { gender } \\
\text { phenome } \\
\text { non in } \\
\text { art } \\
\text { performa } \\
\text { nce }\end{array}$ & $\begin{array}{l}\text { accept } \\
\text { ed }\end{array}$ & $\begin{array}{l}\text { accepte } \\
\text { d }\end{array}$ & Bias \\
\hline 4 & $\begin{array}{l}\text { Limens } \\
\text { position } \\
\text { of man } \\
\text { in } \\
\text { woman } \\
\text { role }\end{array}$ & $\begin{array}{l}\text { accept } \\
\text { ed }\end{array}$ & $\begin{array}{l}\text { accepte } \\
\text { d }\end{array}$ & $\begin{array}{l}\text { Acce } \\
\text { pted }\end{array}$ \\
\hline 5 & $\begin{array}{l}\text { Role as } \\
\text { subject } \\
\text { in each } \\
\text { both } \\
\text { man and } \\
\text { woman } \\
\text { body }\end{array}$ & $\begin{array}{l}\text { accept } \\
\text { ed }\end{array}$ & bias & bias \\
\hline
\end{tabular}

Based on the above table, it can be seen that issue of gender 
relationship in traditional art performance indicates 'chaos' of man and woman roles both as 'self' and 'they selves' and their condition in social acceptance.

Some traditional art experts, as in Cirebon, said that if the role of woman topeng dancer gets social legitimate as 'empu'. This is caused by spiritual reason, for example, woman is able to carry out reproduction massage as in topeng panji that reveals the early philosophy of universe creation like new baby who has minimum movement and has not already been colored by action at all. If this cultural load gets justice treatment in dignity and equality both in public and economy, surely, it will be ideal, yet, if there is any sexual flatter, injustice in work load proportion and income, certainly, it needs reasoning for its advocating.

\section{Viewpoint of gender justice}

Issue of woman as actress of traditional art performance has not already got much attention in its justice and equality and still focusing on economy, politic, social, and education. Although issue of culture, especially art performance is still marginalized in gender mainstream, it does not mean that no attention given, because woman expression in art performance indicates expression of potential, intellectual capacity, and dedication to society through art sector. Woman art experts such as Miss Tjitjih, Srimulat, Christine Hakim, even actress in villages who dedicate their life for art need much attention. Further, there are many traditional art performances that are organized professionally by woman, led by woman, developed by woman, and played by woman, yet, they have not got much attention in balance roles, functions and rights as individual. Beside, case of gender injustice and inequality even dignity violence those who work in art performance.

In viewpoint of gender justice, discrimination and marginalization of woman social and cultural rights in traditional art performance need to be noted and advocated. This relates with treatment and its positioning in roles of strategic subject in woman dignity. For this interest, we can adopt racism analysis model to give gender justice for traditional art performance actress. The model is determination of gender analysis, as individual racism, institutional racism, and cultural racism.

If woman is related with traditional art performance, then individual racism relates with indicators as (a) behavior discriminating and subordinating woman in art, (b) attitude to woman who susceptible to violence and dignity. Institutional racism relates with indicators of (a) position as art workers who need much attention and gender analysis, (b) law protection, if they get injustice treatment relating with their job in art performance, (c) equality and justice in economy, both as individual who have potential and professionalism and access to credit from banks in operating their art efforts, and (d) social comfort, such as expectation in health and housing. While in cultural racism, indicators that need to be seen are (a) expression of esthetic in dignity, (b) 
normative and ethic values in associating among artists and art audiences.

\section{BIBLIOGRAPHY}

Prihartini, N. S. (2003). Dolalak: Kesenian Rakyat Unggulan
Kabupaten Purworejo Jawa Tengah. Mudra, 11(1).

Simatupang, Y. S. (2005). Cross Gender Didik Nini Thowok. Malang: Sava Media. 